\title{
Tinjauan Yuridis Penyelenggaraan Pemungutan Retribusi Pelayanan Parkir Di Tepi Jalan Umum
}

\author{
Muhammad Ishomudin \\ Program Pascasarjana Fakultas Hukum Universitas Islam Indonesia \\ Jln. Cik Di Tiro No. 1, Yogyakarta, 55223 \\ muh.ishomudin@gmail.com
}

\begin{abstract}
This study aims to analyze the implementation of the Bantul District Regulation No. 19 of 2015 on Road Traffic and Transportation Network (Bantul District Regulation) in regard to parking on the public roadside in Bantul. This research is motivated by the large number of public roadside used as vehicle parking lots by most people in Bantul District. The formulation of the problems is: how is the implementation of the Bantul District Regulation in providing parking on public roadside? what is the process for applying for a roadside parking permit?; what is the surveillance system for collecting roadside parking fees?; and what is the legal step of the Bantul Regency Government if the application of public roadside parking violates the provisions in the licensing?. This research uses a juridicalempirical method by collecting data through literature and field studies with qualitative-descriptive analysis. The results showed that Regional Regulation No. 09 of 2011 on Public Service Levies cannot be used as a basis for parking service providers. The Bantul District Government then issued a Bantul District Regulation that gave authority to the Department of Transportation. But in reality, many parking providers have postponed parking fee payments to the Department of Transportation.
\end{abstract}

Keywords: Bantul district government; bantul district regulation; parking service providers; levies

\begin{abstract}
Abstrak
Penelitian ini bertujuan untuk menganalisis implementasi Peraturan Daerah Kabupaten Bantul No. 19 tahun 2015 tentang Jaringan Lalu Lintas dan Angkutan (Perda Kabupaten Bantul) terkait parkir di tepi jalan umum di Bantul. Penelitian ini dilatarbelakangi oleh banyaknya bahu jalan yang digunakan sebagai tempat parkir kendaraan oleh sebagian besar masyarakat Kabupaten Bantul. Adapun rumusan masalahnya: bagaimana implementasi Perda Kabupaten Bantul dalam menyediakan parkir di tepi jalan umum?; bagaimana proses untuk mengajukan izin parkir di tepi jalan umum?; bagaimana sistem pengawasan untuk pengumpulan retribusi parkir di tepi jalan umum? dan apa langkah hukum Pemerintah Kabupaten Bantul jika penerapan parkir di tepi jalan umum melanggar ketentuan dalam perizinan?. Penelitian ini menggunakan metode yuridis-empiris dengan mengumpulkan data melalui studi pustaka dan lapangan dengan analisis kualitatif-deskriptif. Hasil penelitian menunjukkan bahwa Perda No. 09 Tahun 2011 tentang Retribusi Layanan Publik tidak dapat digunakan sebagai dasar bagi penydia parkir. Pemerintah Kabupaten Bantul lalu mengeluarkan Perda Kabupaten Bantul yang memberikan kewenangan kepada Departemen Perhubungan. Namun pada kenyataannya, banyak penyedia parkir yang menunda setoran retribusi parkir ke Departemen Perhubungan.
\end{abstract}

Kata-kata Kunci: Pemerintah daerah kabupaten Bantul; perda kabupaten Bantul; penyelenggara parker; retribusi 


\section{Pendahuluan}

Negara adalah institusi yang terbentuk dari keberadaan suatu kelompok manusia yang bertempat tinggal dalam suatu wilayah atau territorial tertentu kemudian membentuk suatu peraturan-peraturan dalam rangka pengaturan hidup kelompok seperti yang diinginkan bersama. ${ }^{1}$ Setiap negara di dunia dalam menyelenggarakan pemerintahan mempunyai tugas dan kewajiban berbeda-beda, salah satunya adalah negara Indonesia. Dalam menyelenggarakan pemerintahan negara mempunyai kewajiban untuk melindungi dan menjaga rakyat dalam berbagai bidang seperti dalam bidang sosial, politik, keamanan, ekonomi, maupun budaya.

Kewajiban tersebut telah sesuai dengan tujuan negara Indonesia yang dicantumkan di dalam Pembukaan Undang-Undang Dasar Negara Republik Indonesia tahun 1945 pada alinea keempat yang berbunyi “...Pemerintahan Negara Indonesia yang melindungi segenap bangsa Indonesia dan seluruh tumpah darah Indonesia dan untuk memajukan kesejahteraan umum, mencerdaskan kehidupan bangsa, dan ikut melaksankan ketertiban dunia yang berdasarkan kemerdekaan, perdamaian abadi dan keadilan sosial..."

Indonesia adalah negara hukum yang berdasarkan Pancasila dan UndangUndang Dasar Negara Republik Indonesia 1945 (UUD 1945). Pemerintah adalah entitas masyarakat dalam suatu negara yang diberi kewenangan untuk menjalankan pemerintahan. $^{2}$ Pemerintah sebagai perantara bertugas untuk melayani dan memenuhi kebutuhan dasar masyarakatnya. Saat ini pemerintah Indonesia sangat gencar melakukan pembangunan di berbagai aspek. Pembangunan yang dilakukan oleh pemerintah setiap tahunnya mengalami perkembangan yang pesat. Pada hakekatnya pembangunan yang dilakukan secara terus-menenrus memiliki tujuan yaitu untuk mensejahterakan dan memakmurkan masyarakat.

Pembangunan yang dilakukan memerlukan dana yang besar. Untuk memperlancar pembangunan diperlukan suatu dana yang berasal dari penerimaan negara. Sumber penerimaan negara terdiri dari: ${ }^{3}$

\footnotetext{
${ }^{1}$ Edie Toet Hendratno, Negara Kesatuan, Desentralisasi, dan Federalisme, Graha Ilmu, Yogyakarta, 2009, hlm. 46.

2 Mustaqiem, Pajak Daerah dalam Transisi Otonomi Daerah, Ctk. Pertama, FH UII Press, Yogyakarta, 2008, hlm. 1.

${ }_{3}^{3}$ Bohari, Pengantar Hukum Pajak, PT Raja Grafindo Persada, Jakarta, 2002, hlm. 11.
} 
1. Bumi, air, dan kekayaan alam;

2. Pajak-pajak, Bea dan Cukai;

3. Penerimaan Negara, Bukan Pajak (non-tax);

4. Hasil Perusahaan Negara;

5. Sumber-sumber lain, seperti: pencetakaan uang dan pinjaman.

Berdasarkan sumber penerimaan negara diatas, bahwa pajak merupakan salah satu sumber utama Anggaran Pendapatan dan Belanja Negara yang mempunyai peranan penting dalam pembangunan. Penerimaan negara yang paling banyak berasal dari sektor pajak. Setiap tahunnya penerimaan negara yang berasal dari pajak mengalami peningkatan.

Kemudian, pemerintah berupaya untuk mengoptimalkan penerimaan negara yang berasal dari pajak. Berbagai macam kebijakan perpajakan sudah pernah dilakukan oleh pemerintah. Saat ini landasan hukum bidang perpajakan di Indonesia secara yuridis konstitusional mengacu pada Pasal 23A UUD 1945 yang berbunyi: "Pajak dan pungutan lain yang bersifat memaksa untuk keperluan negara diatur dengan Undang-Undang".

Indonesia sebagai negara kesatuan menganut sebuah sistem desentralisasi, dimana sistem tersebut sebuah sistem pemencaran kekuasaan secara vertikal dalam sebuah negara kesatuan. Untuk pemencaran secara vertikal adalah adanya pemerintahan daerah dengan segala kewenangan yang telah ditentukan oleh undangundang. Salah satu kewenangan pemerintahan daerah adalah memungut retribusi dan pajak daerah sebagai pendapatan asli daerah. Pajak dan retribusi daerah mempunyai peranan yang sangat penting untuk membiayai penyelenggaraan pemerintah daerah dan pembangunan daerah serta bagi penerimaan kas daerah.

Pemerintah pusat dengan pemerintah daerah memiliki hubungan keuangan dalam hal membiayai penyelenggaraan pemerintahan. Pemerintah pusat memberikan kewenangan atau menyerahkan kepada daerah untuk menyelenggarakan pemerintahan di daerah. Hubungan keuangan pemerintah pusat yang telah menyerahkan urusan daerah kepada pemerintah daerah, meliputi:4

1. Pemberian sumber penerimaan Daerah berupa pajak daerah dan retribusi daerah;

${ }^{4}$ Undang-Undang Nomor 23 Tahun 2014 tentang Pemerintahan Daerah, Pasal 279 ayat (2). 
2. Pemberian dana bersumber dari perimbangan keuangan antara Pemerintah Pusat dan Daerah;

3. Pemberian dana penyelenggaraan otonomi khusus untuk Pemerintahan Daerah tertentu yang ditetapkan dalam undang-undang; dan

4. Pemberian pinjaman dan/atau hibah, dana darurat, dan insentif (fiskal).

Dalam rangka penyelenggaraan pemerintahan daerah, tiap-tiap daerah mempunyai hak dan kewajiban untuk mengatur dan mengurus sendiri pemerintahan yang berada di daerahnya. Hal tersebut bertujuan untuk meningkatkan efektivitas dan efisiensi penyelenggaraan pemerintahan dan pelayanana kepada masyarakat guna pelaksanaan pembangunan daerah. Untuk merealisasikan pembangunan daerah dalam rangka menyelenggarakan pemerintahan dan pelayanan kepada masyarakat, maka pemerintah membutuhkan dana yang besar. Pemerintah daerah mempunyai kewajiban untuk menggali segala potensi yang ada di daerahnya guna meningkatkan sumber pendapatan asli daerah.

Retribusi daerah merupakan salah satu sumber pemasukan pendapatan asli daerah. Retribusi daerah diharapkan mampu membiayai penyelenggaraan pemerintah daerah, karena retibusi daerah berperan cukup penting dalam pemasukan pendapatan asli daerah. Pemerintah daerah dapat melakukan pemungutan terhadap retribusi yang berada di daerahnya. Dalam pemungutan retribusi daerah, pemerintah harus membuat sebuah peraturan perundang-undangan tentang retrbusi daerah.

Seiring berjalannya waktu, jumlah atau volume dan pengguna kendaraan bermotor di Kabupaten Bantul mengalami peningkatan dari tahun ke tahun. Dimana setiap keluarga memiliki kendaraan bermotor lebih dari satu. Meningkatnya jumlah dan pengguna kendaraan bermotor menyebabkan kepadatan dijalan raya dan meningkatnya kebutuhan masyarakat akan lahan atau tempat untuk parkir. Oleh karena itu, pemerintah kabupaten bantul membuat suatu peraturan perundangundangan tentang parkir. Kemudian, pemerintah Kabupaten Bantul mengeluarkan Perda No. 19 Tahun 2015 tentang Jaringan Lalu Lintas dan Angkutan Jalan (Perda Kabupaten Bantul) untuk memberikan perlindungan hukum terhadap pengguna kendaraan bermotor dan pengelola parkir.

Dengan dikeluarkannya Perda Kabupaten Bantul yang didalamnya mengatur penyelenggaraan parkir, diharapkan masyarakat merasa aman dan nyaman saat 
memarkirkan kendaraannya dan petugas parkir memiliki tanggung jawab menjaga kendaran serta dapat meningkatkan pendapatan asli daerah dari retribusi parkir. Pendapatan dari retribusi parkir memberikan kontribusi yang cukup besar terhadap pendapatan asli daerah. Dalam memaksimalkan pendapatan dari retribusi parkir, pemerintah daerah yang diwakili oleh Dinas Perhubungan melakukan perjanjian dengan pengelola parkir untuk menghitung dan menyetorkan hasil yang didapat dari parkir selama satu bulan penuh.

Akan tetapi, pada faktanya masih terdapat beberapa petugas parkir banyak yang melanggar peraturan tersebut. Beberapa contoh juru parkir yang melanggar yaitu para juru parkir memanfaatkan lahan yang seharusnya tidak boleh digunakan untuk parkir para juru atau pengelola parkir ada yang belum mengetahui tentang perjajian retribusi parkir, kemudian beberapa juru parkir atau pengelola parkir yang belum memiliki surat izin dari pihak terkait, banyak para petugas atau pengelola parkir terlambat untuk membayar/menyetorkan uang tiap bulannya, terkadang tidak diberikan karcis parkir oleh juru parkir, serta beberapa penjaga parkir tidak mengetahui bagaimana proses perjanjian maupun isi perjanjian antara pengelola parkir dengan pihak berwenang dari pemerintah.

Berdasarkan uraian di atas, penulis tertarik untuk melakukan penelitian tentang penyelenggaraan retribusi parkir, yang merupakan salah satu penyumbang pajak dan retribusi daerah yang diharapkan dapat memberikan kontribusi yang besar dalam peningkatan pendapatan asli daerah sehingga dapat mewujudkan dan merealisasikan penyelenggaraan pemerintahan daerah.

\section{Rumusan Masalah}

Adapun permasalahan hukum yang dipaparkan dalam penelitian ini sebagai berikut: pertama, bagaimana penerapan Perda Kabupaten Bantul dalam penyediaan tempat parkir di tepi jalan umum di Kabupaten Bantul? Kedua, bagaimana proses hukum pengajuan izin penyelenggaraan parkir di tepi jalan umum dengan pihak ketiga di Kabupaten Bantul? Ketiga, bagaimana sistem pengawasan terhadap pelaksanaan pemungutan retribusi parkir di tepi jalan umum di Kabupaten Bantul? Keempat, bagaimana langkah hukum Pemerintah Daerah apabila penyelenggaraan parkir di tepi jalan umum melakukan pelanggaran ketentuan dalam perizinan? 


\section{Tujuan Penelitian}

Berangkat dari rumusan masalah tersebut, penelitian ini bertujuan untuk: pertama, untuk mengetahui bagaimana penerapan Perda Kabupaten Bantul dalam penyedian tempat parkir di tepi jalan umum di Kabupaten Bantul. Kedua, untuk mengetahui proses hukum pengajuan izin penyelenggaraan pemungutan retribusi parkir di Kabupaten Bantul. Ketiga, untuk mengetahui sistem pengawasan terhadap pelaksanaan isi perjanjian dalam pemungutan retribusi parkir di Kabupaten Bantul. Keempat, untuk mengetahui langkah hukum Pemerintah Daerah apabila penyelenggaraan parkir di tepi jalan umum melakukan pelanggaran ketentuan dalam perizinan.

\section{Metode Penelitian}

Metode penelitian yang digunakan adalah penelitian hukum empiris, yaitu penelitian dengan mencari data-data lapangan yang bersangkut paut dengaan isu hukum yang sedang ditangani atau diteliti untuk kemudian dikaji berdasarkan peraturan perundang-undangan yang berlaku. Selanjutnya hasil penelitian tersebut dianalisis dengan cara deskriptif kualitatif yakni mengumpulkan dan menyeleksi bahan hukum yang sesuai dengan permasalahan yang akan diteliti atau data yang diperoleh dari studi kepustakaan maupun data lapangan (wawancara), kemudian dideskripsikan dan dipaparkan secara sistematis.

\section{Hasil Penelitian dan Pembahasan}

\section{Penerapan Perda Kabupaten Bantul dalam Penyediaan Tempat Parkir di Tepi Jalan Umum}

Setiap tahun pertumbuhan penduduk di kabuaten Bantul selalu meningkat. Pada 2018 jumlah penduduk di Kabupaten Bantul kurang lebih sekitar 955.000 orang. Seiring dengan meningkatnya atau bertambahnya jumlah peduduk tersebut, maka bertambah banyak jumlah atau volume kendaraan bermotor di wilayah Kabupaten Bantul setiap tahunnya. Setiap satu keluarga memiliki kendaraan bermotor lebih dari satu jenis kendaraan. Meningkatnya jumlah kendaraan bermotor tersebut berdampak semakin padatnya kendaraan di jalan raya yang menyebabkan 
kemacetan serta meningkatkan kebutuhan masyarakat akan lahan parkir atau tempat untuk parkir kendaraan. Oleh karena itu, pemerintah Kabupaten Bantul membuat suatu peraturan perundang-undangan yang mengatur tentang tempat parkir atau penyelenggaraan parkir di tepi jalan umum.

Kemudian pemerintah menindaklanjuti masalah tersebut dengan mengeluarkan Peraturan Daerah Nomor 09 Tahun 2011 tentang Retribusi Jasa Umum (Perda Retribusi). Peda Retribusi Jasa Umum hanya mengatur pemungutan tarif parkir dan besarnya tarif parkir, tidak dapat dijadikan landasan hukum maupun pedoman bagi para pihak penyelenggara parkir di kawasan Kabupaten Bantul. ${ }^{5}$ Kemudian besarnya tarif parkir tersebut dirubah dan diganti dengan Peraturan Bupati Bantul Nomor 78 Tahun 2017 tentang Penyesuaian Tarif Retribusi Pelayanan Parkir di Tepi Jalan Umum (Peraturan Bupati Bantul).

Selanjutnya peraturan yang mengatur tentang pajak daerah dan retribusi daerah yaitu UU No. 28 Tahun 2009 tentang Pajak Daerah dan Retribusi Daerah (UU Pajak Daerah). Dalam Pasal 150 (a) UU Pajak Daerah disebutkan terdapat beberapa kriteria atau ciri-ciri yang melekat mengenai retribusi daerah yaitu:

1. Retribusi Jasa Umum bersifat bukan pajak dan bersifat bukan Retribusi Jasa Usaha atau Retribusi Perizinan Tertentu;

2. Jasa yang bersangkutan merupakan kewenangan daerah dalam rangka pelaksanaan desentralisasi;

3. Jasa tersebut memberi manfaat khusus bagi orang pribadi atau Badan yang diharuskan membayar retribusi, disamping untuk melayani kepentingan dankemanfaatan umum;

4. Jasa tersebut hanya diberikan kepada orang pribadiatau Badan yang membayar retribusi dengan memberikan keringanan bagi masyarakat yang tidak mampu;

5. Retribusi tidak bertentangan dengan kebijakan nasional mengenai penyelenggaraannya;

6. Retribusi dapat dipungut secara efektif dan efisien, serta merupakan salah satu sumber pendapatan Daerah yang potensial; dan

7. Pemungutan Retribusi memungkinkan penyediaan jasa tersebut dengan tingkat dan/atau kualitas pelayanan yang lebih baik.

Menurut Rochmat Soemitro, pajak adalah peralihan kekayaan dari pihak rakyat kepada kas negara untuk membiayai pengeluaran rutin dan surplusnya

${ }^{5}$ Hasil Wawancara dengan Bapak Agung, Kepala bagian unit Lalu Lintas Dinas Perhubungan Bantul, Senin, 10 Desember 2018. 
digunakan untuk publik saving yang merupakan sumber utama untuk membiayai publik invesment. ${ }^{6}$ Sedangkan pengertian retribusi adalah pembayaran wajib dari penduduk kepada negara karena adanya jasa tertentu yang diberikan oleh negara bagi penduduknya secara perseorangan. ${ }^{7}$

Pengertian Pajak Daerah dalam Pasal 1 ayat (10) UU Pajak Daerah, yang dimaksud pajak daerah adalah kontribusi wajib kepada daerah yang terutang oleh orang pribadi atau badan yang bersifat memaksa berdasarkan undang-undang, dengan tidak mendapatkan imbalan secara langsung dan digunakan untuk keperluan daerah bagi sebesar-besarnya untuk kemakmuran rakyat. Pajak daerah adalah iuran wajib yang dilakukan oleh orang pribadi atau badan kepada daerah tanpa imbalan langsung yang seimbang, yang dapat dipaksakan berdasarkan peraturan perundangundangan yang berlaku, yang digunakan untuk membiayai penyelenggaraan pemerintah daerah dan pembangunan. ${ }^{8}$ Sedangkan pengertian retribusi daerah adalah pungutan yang dilakukan oleh pemerintah daerah atas pelayanan dan penggunaan fasilitas-fasilitas umum yang disediakan oleh pemerintah daerah bagi kepentingan masyarakat, sesuai dengan Peraturan Daerah yang berlaku. ${ }^{9}$

Jadi perbedaan antara pajak dengan retribusi yaitu: ${ }^{10}$

1. Kontra prestasinya, pada retribusi kontra prestasinya dapat ditunjuk secara langsung, sedangkan pada pajak kontra prestasinya tidak dapat ditunjuk secara langsung.

2. Balas jasa pemerintah, pajak balas jasa pemerintah berlaku untuk umum; seluruh rakyat menikmati balas jasa, baik yang membayar pajak maupun yang dibebaskan dari pajak. Sebaliknya, pada retribusi balas jasa pemerintah berlaku khusus, yaitu hanya dinikmati oleh pihak yang telah melakukan pembayaran retribusi.

3. Sifat pemungutannya, pajak bersifat umum artinya bahwa berlaku untuk setiap orang yang memenuhi syarat untuk dikenakan pajak. Sedangkan retribusi hanya berlaku untuk orang tertentu, yaitu yang menikmati jasa pemerintah yang dapat ditunjuk.

4. Sifat pelaksanaannya, retribusi sifat paksaannya bersifat ekonomis artinya bahwa bagi setiap orang yang ingin mendapatkan suatu jasa tertentu dari pemerintah harus membayar retribusi. Sedangkan, sifat paksaan pada pajak

\footnotetext{
${ }^{6}$ Muyassarotussolichah, Hukum Pajak, Cetakan Pertama, Penerbit Teras, Yogyakarta, 2008, hlm. 4.

${ }^{7}$ Marihot P. Siahaan, Pajak Daerah dan Retribusi Daerah, PT Raja Grafindo Persada, Jakarta, 2006, hlm. 5.

${ }^{8}$ Liberty Pandiangan, Undang-Undang Perpajakan Indonesia, Gramedia, Jakarta, 2002, hlm. 10.

9 Indra Bastian, Manual Akuntansi Keuangan Pemerintah Daerah, BPFE, Yogyakarta, 2001, hlm. 156.

${ }_{10}$ Marihot P. Siahaan, Op. Cit., hlm. 11.
} 
adalah yuridis, artinya bahwa setiap orang yang melanggar akan mendapat sanksi hukuman, baik berupa sanksi pidana maupun denda.

5. Lembaga atau badan pemungutnya, pajak dapat dipungut oleh pemerintah pusat maupun pemerintah daerah, sedangkan retribusi hanya dapat dipungut oleh pemerintah daerah.

Setelah diundangkan Perda Retribusi Jasa Umum, pada kenyataannya peraturan tersebut tidak dapat dijadikan dasar hukum atau pedoman bagi penyelenggara parkir. Karena Pemerintah Kabupaten Bantul membuat dan mengeluarkan peraturan daerah yang baru yaitu Perda Kabupaten Bantul. Peraturan daerah tersebut dibuat untuk memberikan perlindungan hukum terhadap pengguna kendaraan bermotor dan sebagai dasar hukum atau pedoman bagi pengelola parkir atau penyelenggara parkir.

Setelah diundangkannya Perda Kabupaten Bantul tersebut, diharapkan masyarakat akan selalu merasa aman dan nyaman saat memarkirkan kendaraannya dan petugas parkir memiliki tanggung jawab menjaga kendaraan yang diparkirkan serta dapat meningkatkan pendapatan asli daerah melalui retribusi parkir. Pendapatan dari retribusi parkir tersebut memberikan kontribusi yang dan dampak cukup besar terhadap pendapatan asli daerah.

Pendapatan asli daerah tidak hanya bersumber dari retribusi daerah, tetapi bersumber dari pajak daerah, salah satunya adalah pajak parkir. Pajak parkir dengan retribusi parkir memiliki dasar hukum atau dua aturan yang berbeda. Pajak parkir diatur dalam Peraturan Daerah No. 8 Tahun 2010 tentang Pajak Daerah (Perda Pajak Daerah), sedangkan retribusi parkir diatur dalam Perda Kabupaten Bantul. Sistem dan mekanisme pemungutan antara pajak parkir dengan retribusi parkir juga berbeda.

\section{Proses Hukum dalam Pengajuan Izin Penyelenggaraan Pemungutan Retribusi Parkir di Tepi Jalan Umum di Kabupaten Bantul}

Setiap tahunnya di Indonesia jumlah kendaraan bermotor semakin meningkat. Perbandingan jumlah kendaraan bermotor yang setiap tahunnya mengalami peningkatan, tidak diimbangi dengan luas jalan yang tidak meningkat. Seiring bejalannya waktu, setiap tahun ketersedian lahan parkir atau tempat parkir semakin bertambah. Karena setiap tahun jumlah kendaraan bermotor tidak semakin berkurang, akan tetapi semakin meningkat. Maka dibutuhkan 
pembukaan lahan-lahan atau tempat-tempat baru untuk parkir kendaraan bermotor. Kemudian para penyelenggara parkir membuka lahan atau tempat parkir di tepi jalan umum. Untuk dapat pmembuka lahan atau tempat parkir, para penyelenggara parkir mengajukan izin kepada pemerintah daerah. Penyelenggara parkir tersebut ada yang perseorangan dan ada yang berbadan hukum.

Para penyelenggara parkir di tepi jalan umum dalam menyelenggarakan pemungutan retribusi parkir di tepi jalan umum mengacu pada Perda Kabupaten Bantul. Perda tersebut juga dijadikan dasar hukum tepi jalan umum dapat dijadikan tempat atau lahan untuk parkir. Dalam Peraturan Daerah tersebut terdapat beberapa pasal yang mengatur berbagai macam tentang parkir seperti:

1. Fasilitas Parkir Umum;

2. Fasilitas Parkir Umum di Luar Ruang Milik Jalan;

3. Penyediaan Fasilitas Parkir;

4. Pengelolaan Fasilitas Parkir Milik Pemerintah Daerah;

5. Fasilitas parkir di Dalam Ruang Milik Jalan;

6. Kewajiban dan Tanggung Jawab Penyelenggara Parkir;

7. Perizinan Parkir;

8. Pemanfaatan Penerimaan Retribusi Perparkiran; dan

9. Fasilitas Pendukung.

Berdasarkan penjelasan di atas, bahwa Perda Kabupaten Bantul merupakan dasar hukum untuk pengelola parkir dalam menyelenggarakan pemungutan retribusi parkir karena di dalam perda tersebut diatur bagaimana mekanisme, cara, tata urutan dalam menyelenggarakan pemungutan retribusi parkir.

Terdapat beberapa cara untuk menentukan apakah tindakan atau perbuatan pemerintah tersebut masuk dalam hukum privat atau hukum publik adalah dengan melihat kedudukan pemerintah dalam menjalankan perbuatan atau tindakan tersebut. Apabila pemerintah bertindak dalam kedudukan sebagai pemerintah, maka yang berlaku adalah hukum publik, sedangkan pemerintah bertindak tidak dalam kapasitas sebagai pemerintah, maka yang berlaku adalah hukum privat.

Berikut adalah alur atau proses pengajuan izin parkir di tepi jalan umum, penjelasannya sebagai berikut:

1) Penyelenggara parkir mengajukan surat permohonan izin parkir kepada pemerintah daerah (Dinas Perhubungan); 
2) Kemudian mengisi formulir permohonan dengan melengkapi beberapa persyaratan sebagai berikut:

a. Pas foto ukuran $3 \times 4$ sebanyak 3 lembar;

b. Fotocopy kartu tanda penduduk (KTP);

c. Denah lokasi parkir;

d. Keterangan lainnya sebagai pendukung surat keterangan;

e. Kerelaan tempat; dan

f. Rekomendasi dari wilayah yaitu RT, Pedukuhan dan Kelurahan.

3) Kemudian lokasi yang akan dijadikan tempat parkir akan di survey dan ditinjau oleh tim appresial dari Dinas Perhubungan;

4) Apabila dinyatakan layak, kemudian diajukan ke proses pembuatan surat izin; dan

5) Penerbitan surat izin parkir, setelah zurat izin terbit penyelenggara parkir segera menandatangi kesepakatan pembagian hasil retribusi parkir kemudian disetorkan kepada pemerintah daerah melalui Dinas Perhubungan, hasil setoran tersebut kemudian disebut dengan retribusi daerah.

Berdasarkan hal tersebut, dalam hal ini pemerintah melakukan tindakan/perbuatan berdasarkan dengan peraturan perundang-undangan yang ada yaitu peraturan daerah. Perbuatan atau tindakan tersebut dilakukan oleh pemerintah dalam kedudukannya sebagai penguasa dan dalam rangka menjalankan fungsi pemerintahan.

Tindakan pemerintah (bestuurshandeling) adalah setiap tindakan atau perbuatan yang dilakukan oleh alat perlengkapan pemerintahan (bestuursorgaan) dalam menjalankan fungsi pemerintahan (bestuursfunctie). ${ }^{11}$ Kemudian menurut Romeijn, tindakan hukum pemerintah merupakan suatu pernyataan kehendak yang muncul dari organ administrasi dalam keadaan khusus, dimaksudkan untuk menimbulkan akibat hukum dalam bidang hukum administrasi. ${ }^{12}$

Tindakan pemerintah tersebut termasuk dalam perbuatan hukum publik bersegi satu. tidak ada perbuatan hukum publik yang bersegi dua, tidak ada perjanjian, jika pemerintah mengadakan perjanjian dengan pihak swasta maka perjanjian itu menggunakan hukum privat, tidak ada perjanjian menurut hukum publik karena hubungan hukum yang diatur oleh hukum publik hanya berasal dari satu pihak saja yaitu pemerintah dengan cara menentukan kehendaknya sendiri. hlm. 145.

11 Riawan Tjandra, Hukum Administrasi Negara, Hukum Administrasi Negara, Sinar Grafika, Jakarta, 2018, 12 Ibid. 
Tindakan atau perbuatan pemerintah memiliki unsur-unsur meliputi: ${ }^{13}$

1. Perbuatan itu dilakukan oleh aparat pemerintah dalam kedudukannya sebagai penguasa maupun sebagai alat perlengkapan pemerintahan (bestuursorganen) dengan prakarsa dan tanggung jawab sendiri;

2. Perbuatan tersebut dilaksankan dalam rangka menjalankan fungsi pemerintahan;

3. Perbuatan tersebut dimaksudkan sebagai sarana untuk menimbulkan akibat hukum di bidang hukum administrasi;

4. Perbuatan yang bersangkutan dilakukan dalam rangka pelaksanaan kepentingan negara dan rakyat; dan

5. Perbuatan itu didasarkan pada peraturan perundang-undangan.

Pemerintah dalam menjalankan tugas pemerintahan tidak dapat menggunakan hukum privat, karena sifat hukum privat itu mengatur hubungan hukum yang merupakan kehendak kedua belah pihak dan bersifat perseorangan, sedangkan hukum administrasi negara merupakan bagian dari hukum publik yang merupakan kehendak satu pihak guna melindungi kepentingan umum. ${ }^{14}$

\section{Sistem Pengawasan terhadap Pelaksanaan Pemungutan Retribusi Parkir di Tepi Jalan Umum di Kabupaten Bantul}

Pemerintah daerah melalui Dinas Perhubungan melakukan pengawasan terhadap penyelenggara parkir di wilayah Kabupaten Bantul. Bentuk pengawasannya yang dipimpin oleh Tim Wasdal (pengawasan dan pengendalian) yang beranggotakan dari Dinas Perhubungan Kabupaten Bantul. ${ }^{15}$ Terdapat beberapa tugas yang harus dijalankan oleh tim wasdal, beberapa diantaranya yaitu: ${ }^{16} 1$. Mengawasi dan mengendalikan parkir secara periodik dan berkala; 2. Melakukan pembinaan terhadap parkir liar; dan 3. Membantu penyelenggara parkir memungut retribusi parkir.

Beberapa penyelenggara parkir tidak bisa menyetorkan langsung hasil retribusi parkir kepada dinas perhubungan. Hal tersebut terjadi dikarenakan jarak yang cukup jauh antara tempat penyelenggara parkir dengan tempat untuk menyetorkan retribusi

13 Ibid., hlm. 146.

${ }^{14}$ S.F. Marbun, Hukum Administrasi Negara I, Ctk. Pertama, FH UII Press, Yogyakarta, 2012, hlm. 151.

${ }^{15}$ Hasil Wawancara dengan Bapak Agung, Kepala bagian unit Lalu Lintas Dinas Perhubungan Bantul, Senin, 10 Desember 2018.

16 Ibid. 
parkir yaitu dinas perhubungan. Maka dari dinas perhubungan yang diwakili tim wasdal (pengawasan dan pengendalian) mengambil hasil retribusi parkir dengan mendatangi langsung penyelenggara parkir. ${ }^{17}$ Sebelum mengambil hasil retribusi parkir tersebut, penyelenggara parkir telah berkoordinasi terlebih dahulu dengan dinas perhubungan yang menyatakan bahwa penyelenggara parkir tidak dapat menyetorkan hasil retribusi parkir kepada dinas perhubungan. ${ }^{18}$

Pada kenyataannya, dinas perhubungan sering menemukan beberapa tempat parkir yang tidak memeliki izin parkir atau disebut dengan parkir liar. Dinas perhubungan tidak memiliki kewenangan untuk menindak parkir liar tersebut. Dinas perhubungan hanya bias memberikan peringatan kepada petugas parkir liar untuk segera mengajukan izin parkir ke pemerintah daerah melalui dinas perhubungan. Apabila sudah diperingatkan sampai tiga kali, tetapi tetap tidak mengajukan izin, maka dinas perhubungan melaporkan tempat parkir liar tersebut kepada tim Sapu Bersih Pungutan Liar (Saber Pungli) Kabupaten Bantul.

Pengertian pungli atau pungutan liar adalah perbuatan yang dilakukan oleh seseorang atau pegawai negeri, atau bahkan pejabat negara dengan cara meminta pembayaran sejumlah uang yang tidak sesuai dengan peraturan yang berkaitan dengan pembayaran tersebut. ${ }^{19}$ Dalam Pasal 12 (e) UU No. 30 Tahun 2001 tentang Tindak Pidana Korupsi, yang dimaksud dengan pungutan liar adalah suatu perbuatan yang dilakukan pegawai negeri atau penyelenggara yang dengan maksud menguntungkan diri sendiri atau orang lain secara melawan hukum, atau dengan menyalahgunakan kekuasaannya memaksa seseorang memberikan sesuatu, membayar, atau menerima pembayaran dengan potongan, atau untuk mengerjakan sesuatu bagi dirinya sendiri. ${ }^{20}$ Ada beberapa faktor yang menyebabkan pungli semakin berkembang, faktor-faktornya yaitu:21

1. Rentetan birokrasi yang panjang dan rumit dalam proses pengurusan sehingga hal itu memberikan celah kepada petugas untuk menawarkan kemudahan dengan persyaratan memberikan "uang jasa" dalam jumlah tertentu;

18 Ibid.

${ }^{19}$ Hasil Wawancara dengan Tim Sapu Bersih Pungutan Liar (Saber Pungli) Kabupaten Bantul, Selasa, 18 Desember 2018.

${ }^{20} \mathrm{Ibid}$.

${ }^{21}$ Ibid. 
2. Budaya masyarakat yang tidak mau repot dan enggan mengantre. Mereka yang malas mengantre dan tidak mau repot, cenderung untuk mengambil jalan pintas dengan membayar "uang jasa" agar urusan menjadi lebih cepat;

3. Penghasilan yang bisa dikatakan tidak mencukupi kebutuhan hidup. Hal ini tidak sebanding dengan tugas/jabatan yang diemban sehingga membuat seseorang terdorong untuk melakukan pungli;

4. Budaya organisasi yang berkembang, yakni jika bisa dipersulit, untuk apa harus dipermudah. Budaya inilah yang membuat pungli semakin berkembang;

5. Lemahnya sistem kontrol dalam mengawasi jalannya proses layanan masyarakat sehingga berpeluang berkembangnya pungli;

6. Terbatasnya sumber daya manusia yang andal. Sumber daya yang andal dan berkomitmen sangat diperlukan sehingga masing-masing sumber daya itu dapat bekerja dengan cepat, efisien, dan berkomitmen. Dengan demikian, masyarakat tidak perlu menunggu lama dalam pengurusan, sehingga praktik pungli tidak ada celah untuk berkembang;

7. Mentalitas petugas dan masyarakat harus diperbaiki. Jika masyarakat selalu berpikir jalan pintas dan tidak mau mengikuti aturan yang ada dalam pengurusan, kemuidan di sisi lain petugas memberikan kemudahan dengan imbalan jasa, tentu praktik pungli pun tidak akan dapat diberantas; dan

8. Belum ada ketegasan hukum. Hukum secara tegas harus ditegakkan bagi para petugas dan masyarakat yang terlibat pungli. Dengan demikian, ada efek jera bagi oknum tertentu.

Tim Saber Pungli tersebut mempunyai payung hukum yaitu Peraturan Presiden No. 87 Tahun 2016 tentang Satuan Tugas Sapu Bersih Pungutan Liar (Perpres Saber Pungli) dan Keputusan Bupati Bantul No. 148 Tahun 2018 tentang Pembentukan unit Pemberantasan Pungutan Liar Kabupaten Bantul Tahun Anggaran 2018 (Perda Saber Pungli). Tim Saber Pungli di Kabupaten Bantul memiliki tugas dan wewenang. Tugas Saber Pungli adalah melaksanakan pemberantasan pungutan liar secara efektif dan efisien dengan mengoptimalkan pemanfaatan personil, satuan kerja dan sarana prasarana yang berada di Pemerintah Daerah dan Pemerintah Desa.

Sedangkan wewenangnya yaitu: 22

1. Membangun sistem pencegahan dan pemberantasan pungutan liar;

2. Melakukan pengumpulan data dan informasi dari lembaga dan pihak lain yang terkait dengan menggunakan teknologi informasi;

3. Mengkoordinasikan, merencanakan dan melaksanakan operasi pemberantasan pungutan liar; 
4. Melakukan operasi tangkap tangan;

5. Memberikan rekomendasi kepada pimpinan instansi untuk memberikan sanksi kepada pelaku pungutan liar sesuai dengan ketentuan peraturan perundang-undangan;

6. Memeberikan rekomendasi pembentukan dan pelaksanaan unit satuan tugas pungutan liar di setiap instansi penyelenggara pelayanan publik kepada pimpinan instansi; dan

7. Melaksanakan evaluasi kegiatan pemberantasan pungutan liar.

Tim Saber Pungli tersebut mempunyai susunan organisasi yang dibentuk untuk menjalanakan dan melaksanakan tugas yang telah diberikan sesuai dengan kewenangan Tim Sapu Bersih Pungutan Liar berdasarkan peraturan perundangundangan yang berlaku. Setiap daerah Kabupaten/Kota mempunyai Susunan anggota Tim Saber Pungli yang berbeda-beda dengan daerah lainnya.

Tim Saber Pungli bekerja saat ada laporan atau aduan dari masyarakat bahwa terdapat indikasi sesorang atau di suatu tempat terjadi pungutan liar dan juga tim Saber Pungli melakukan pengawasan secara periodik atau dijadwalkan dengan berkeliling dibeberapa tempat untuk mengecek dan memastikan apakah terdapat indikasi pungutan liar atau tidak. Kemudian apabila terjadi parkir liar yang menindaklanjuti adalah tim Saber Pungli. Tim Saber Pungli mengecek langsung dilapangan apakah terdapat parkir liat atau tidak.

Pada beberapa acara tertentu, bayar parkir kendaraan lebih mahal dari tarif yang telah di tetapkan. Penyebabnya itu merupakan tempat penitipan kendaraan bukan tempat untuk parkir kendaraan, kalau parkir harus ada izin kepada pemerintah daerah. Jadi penitipan kendaraan tersebut tidak termasuk retribusi parkir, sehingga tarif yang dikenakan di tempat penitipan tidak menggunakan tarif yang telah ditetapkan pemerintah dan jauh lebih mahal dibandingkan dengan tempat parkir yang memiliki izin. ${ }^{23}$

Setelah tim Saber Pungli menerima laporan atau aduan dari dinas perhubungan, kemudian tim siber pungli terjun langsung ke lapangan untuk mengecek apakah benar terdapat parkir liar di wilayah tersebut. Tim Saber Pungli tidak langsung memproses secara hukum tempat parkir liar tersebut, tetapi memberikan peringatan kepada petugas parkir liar tersebut, apabila sudah sampai 
tiga kali peringatan tidak di tindaklanjuti, maka tim siber pungli baru akan memproses parkir liar tersebut secara hukum. ${ }^{24}$

\section{Langkah Hukum Pemerintah Daerah Apabila Penyelenggaraan Parkir di Tepi Jalan Umum Melakukan Pelanggaran Ketentuan dalam Perizinan}

Dalam Pasal 285 ayat (1) (a) UU No. 23 Tahun 2014 tentang Pemerintahan Daerah, pendapatan asli daerah terdiri atas:

1. Pajak Daerah;

2. Retribusi Daerah;

3. Hasil pengelolaan kekayaan daerah yang dipisahkan; dan

4. Lain-lain PAD yang sah.

Berdasarkan Pasal 108 UU Pajak Daerah, retribusi daerah digolongkan dalam 3 golongan yaitu

1. Retribusi Jasa Umum

Dalam Pasal 110 ayat (1) Undang-Undang Nomor 28 Tahun 2009 diuraikan bebrapa jenis retribusi jasa umum yaitu:

a. Retribusi Pelayanan Kesehatan;

b. Retribusi Pelayanan Persampahan/Kebersihan;

c. Retribusi Penggantian Biaya Cetak Kartu Tanda Penduduk dan Akta Catatan Sipil;

d. Retribusi Pelayanan Pemakaman dan Pengabuan Mayat;

e. Retribusi Pelayanan Parkir di Tepi Jalan Umum;

f. Retribusi Pelayanan Pasar;

g. Retribusi Pengujian Kendaraan Bermotor;

h. Retribusi Pemeriksaan Alat Pemadam Kebakaran;

i. Retribusi Penggantian Biaya Cetak Peta;

j. Retribusi Penyediaan dan/atau Penyedotan Kakus;

k. Retribusi Pengolahan Limbah Cair;

1. Retribusi Pelayanan Tera/Tera Ulang;

m. Retribusi Pelayanan Pendidikan; dan

n. Retribusi Pengendalian Menara Telekomunikasi.

2. Retribusi Jasa Usaha

Dalam Pasal 127 Undang-Undang Nomor 28 Tahun 2009 diuraikan beberapa jenis retribusi jasa usaha yaitu:

a. Retribusi Pemakaian Kekayaan Daerah;

b. Retribusi Pasar Grosir dan/atau Pertokoan;

c. Retribusi Tempat Pelelangan;

d. Retribusi Terminal; 

e. Retribusi Tempat Khusus Parkir;
f. Retribusi Tempat Penginapan/Pesanggrahan/Villa;
g. Retribusi Rumah Potong Hewan;
h. Retribusi Pelayanan Kepelabuhanan;
i. Retribusi Tempat Rekreasi dan Olahraga;
j. Retribusi Penyeberangan di Air; dan
k. Retribusi Penjualan Produksi Usaha Daerah.

3. Retribusi Perizinan Tertent

Dalam pasal 141 Undang-Undang Nomor 28 Tahun 2009 diuraikan bebrapa jenis retribusi perizinan tertentu yaitu:
a. Retribusi Izin Mendirikan Bangunan;
b. Retribusi Izin Tempat Penjualan Minuman Beralkohol;
c. Retribusi Izin Gangguan;
d. Retribusi Izin Trayek; dan
e. Retribusi Izin Usaha Perikanan.

Berdasarkan hal di atas, retribusi daerah merupakan salah satu penyumbang atau penghasil pendapatan asli daerah. Kemudian dalam retribusi daerah tersebut digolongkan menjadi tiga macam retribusi daerah yaitu retribusi jasa umum, retribusi jasa usaha dan retribusi perizinan tertentu. Dalam hal ini penulis akan fokus terhadap retribusi jasa umum yang dimana retribusi jasa umum terbagi atas 14 jenis salah satunya adalah retribusi pelayanan parkir di tepi jalan umum.

Pajak Daerah dan Retribusi Daerah merupakan penyumbang pendapatan asli daerah bagi daerah Kabupaten/Kota. Dalam Retribusi Daerah terbagi tiga jenis retribusi yaitu retribusi jasa umum, retribusi jasa usaha dan retribusi perizinan tertentu. Retribusi pelayanan parkir di tepi jalan umum merupakan jenis retribusi yang terdapat dalam retribusi jasa umum dan sebagai salah satu penyumbang penerimaan pendapatan asli daerah yang cukup besar. Tiap tahunnya diharapkan pendapatan asli daerah yang berasal dari retribusi pelayanan parkir di tepi jalan umum terus mengalami perkembangan dan peningkatan untuk pembangunan di daerah dan mengatur segala kebutuhan rumah tangga setiap daerah. Semakin tinggi pendapatan asli daerah, maka pembangunan di daerah akan semakin maju.

Dalam Pasal 33 ayat (1) dan (3) Perda Kabupaten Bantul, penyelenggara parkir mempunyai kewajiban yang harus di laksanakan. Kewajiban penyelenggara parkir tersebut antara lain: 
1. Mengawasi, menjamin keamanan dan menertibkan lalu lintas sebagai akibat kegiatan masuk dan ke luar kendaraan ke dan dari tempat parkir dengan menempatkan sarana parkir dan/atau menempatkan petugas parkir;

2. Menyediakan tempat parkir yang sesuai standar teknis yang ditentukan;

3. Melengkapi fasilitas parkir paling sedikit berupa rambu, marka dan media informasi tarif dan waktu;

4. Menjaga keamanan kendaraan yang diparkir; dan

5. Mengganti kerugian kehilangan atau kerusakan kendaraan sesuai kententuan perundang-undangan;

6. Menyediakan fasilitas parkir sepeda motor dan sepeda berdasarkan SRP.

Kemudian apabila penyelenggara parkir melanggar kewajiban tersebut, pihak penyelenggara parkir dapat dikenakan sanksi administratif. Sanksi administratif tersebut terdapat dalam Pasal 33 ayat (4) yang isinya adalah: "setiap orang dan/atau badan yang melanggar ketentuan sebagaimana dimaksud pada ayat (1) dan ayat (2) dikenai sanksi administratif berupa peringatan tertulis, pembatalan izin dan/atau pencabutan izin."

Selanjutnya penyelenggara parkir juga harus bertanggung jawab atas beberapa hal, antara lain:

1. Kendaraan yang parkir di satuan ruang parkir (SRP) yang disediakan;

2. Kewajiban retribusi parkir;

3. Penyediaan pakaian seragam bagi petugas parkir;

4. Keamanan dan ketertiban di tempat parkir; dan

5. Kebersihan, keindahan, dan kenyamanan lingkungan fasilitas parkir.

Selain kewajiban di atas, dalam Pasal 34 ayat (1) penyelenggara parkir wajib menyediakan karcis atau sticker langganan atau hasil cetakan atau komputer sebagai bukti pembayaran penggunaan satuan ruang parkir kepada pengguna jasa parkir. Apabila melanggar atau tidak menyediakan karcis, penyelenggara parkir dapat kenai sanksi administratif berupa: peringatan tertulis, pembatalan izin, dan/ atau pencabutan izin. Dalam kenyataan di lapangan, penyelenggara parkir tidak memberikan karcis kepada pengguna jasa parkir. ${ }^{25}$ Karcis tersebut baru diberikan apabila pengguna jasa parkir meminta karcis parkir tersebut, kalau tidak diminta tidak diberikan karcis. ${ }^{26}$ Karcis parkir tersebut dahulu dibuat oleh Dinas

${ }^{25}$ Hasil Wawancara dengan Bapak Lanang, petugas parkir depan pasar bantul, Jumat, 21 Desember 2018. ${ }^{26} \mathrm{Ibid}$. 
Pendapatan Daerah (sekarang berubah nama menjadi Badan Keuangan Aset daerah) tetapi saat ini karcis parkir dibuat sendiri oleh penyelenggara parkir. ${ }^{27}$ Karcis parkir tersebut tidak menjadi dasar atau patokan pemerintah daerah dalam memungut retribusi parkir. Karena penyelenggara parkir menyetorkan uang hasil retribusi parkir berdasarkan kesepakatan antara penylenggara parkir dengan pemerintah daerah yang diwakili oleh Dinas Perhubungan.

Kesepakatan tentang jumlah uang retribusi parkir yang harus disetorkan, pemerintah daerah yang diwakili oleh dinas perhubungan melakukan suvei apakah jumlah setoran yang diajukan layak atau tidak. Karena saat ini tidak ada mekanisme atau peraturan yang mengatur tentang kesepakatan jumlah uang hasil retribusi yang harus disetorkan. Menurut narasumber, jumlah uang yang harus disetorkan sebelum adanya Peraturan Bupati Bantul yaitu sebesar Rp. 150.000,00.28 Kemudian setelah dikeluarkannya Peraturan Bupati Bantul tersebut jumlah uang yang disetorkan naik 2x lipat yaitu sebesar Rp. 300.000,00.29 Setiap tahunnya jumlah uang yang disetorkan mengalami kenaikan bervariasi yaitu 5\% dan 10\% atau naik Rp. 5.000,00 dan Rp. 10.000,00 tiap tahunnya. ${ }^{30}$ Jadi kenaikan uang hasil retribusi parkir yang harus disetor bervariasi, tidak ada dasar atau patokannya.

Dalam kenyataan di lapangan, terdapat beberapa penyelenggara parkir terlambat untuk menyetorkan hasil retribusi parkir kepada dinas perhubungan. Salah satu alasan penyelenggara parkir terlambat untuk menyetor uang yaitu karena malas. ${ }^{31}$ Jadi untuk menyetorkan uang retribusi parkir tidak sebulan sekali, tetapi kadang-kadang dua-tiga bulan sekali baru disetorkan kepada Dinas Perhubungan. Kemudian terdapat beberapa alasan lain para penyelenggara parkir terlambat menyetorkan uang hasil retribusi parkirnya kepada Dinas Perhubungan antara lain:32 1. Jarak yang cukup jauh; dan 2. Kesibukan penyelenggara parkir.

Uang hasil retribusi parkir yang terlambat menyetorkan tersebut tidak termasuk dalam kategori utang kepada dinas perhubungan. Para penyelenggara

\footnotetext{
${ }^{27}$ Ibid.

${ }^{28}$ Hasil Wawancara dengan Bapak Edy, petugas parkir depan pasar bantul, Jumat, 21 Desember 2018.

${ }^{29}$ Ibid.

${ }^{30}$ Ibid.

${ }^{31}$ Hasil Wawancara dengan Bapak Lanang, petugas parkir depan pasar bantul, Jumat, 21 Desember 2018.

${ }^{32}$ Hasil Wawancara dengan Bapak Agung, Kepala bagian unit Lalu Lintas Dinas Perhubungan Bantul,
} Senin, 10 Desember 2018. 
parkir yang terlambat menyetorkan uang hasil pemungutan parkir tersebut tidak dikenakan sanksi maupun denda oleh Dinas Perhubungan. ${ }^{33}$ Karena dalam Perda Kabupaten Bantul, tidak diatur mengenai sanksi yang diberikan terhadap penyelenggara parkir yang terlambat menyetorkan uang hasil pemungutan parkir tersebut. ${ }^{34}$ Jadi uang tersebut masuk ke dalam piutang dinas perhubungan bukan termasuk dalam utang.

\section{Penutup}

Dari penulisan di atas, dapat disimpulkan bahwa pertama, Perda Retribusi Jasa Umum hanya mengatur pemungutan tarif parkir dan besarnya tarif parkir, sehingga Perda tersebut tidak dapat dijadikan landasan hukum maupun pedoman bagi para pihak penyelenggara parkir di kawasan Kabupaten Bantul. Untuk mengatasi hal tersebut, Pemerintah Kabupaten Bantul mengeluarkan Perda Kabupaten Bantul, yang memberikan kewenangan pengelolaan parkir di tepi jalan umum kepada Dinas Perhubungan. Perda tersebut dibuat untuk memberikan perlindungan hukum terhadap pengguna kendaraan bermotor dan sebagai dasar hukum atau pedoman bagi pengelola parkir atau penyelenggara parkir agar para penyelenggara parkir dan masyarakat merasa aman dalam memarkirkan kendaraannya. Kedua, para penyelenggara parkir terlebih dahulu harus mengurus izin kepada Dinas Perhubungan untuk dapat meggunakan tepi jalan sebagai tempat parkir kendaraan. Proses hukum yang harus dilakukan penyelengara parkir dalam pengajuan izin parkir di tepi jalan umum di Kabupaten Bantul dilakukan dengan beberapan tahapan. Berdasarkan hal tersebut, pemerintah bertindak berdasarkan peraturan perundang-undangan yang ada. Tindakan tersebut dilakukan oleh pemerintah dalam kedudukannya sebagai penguasa dan dalam rangka menjalankan fungsi pemerintahan. Ketiga, Pemerintah daerah melalui Dinas Perhubungan melakukan pengawasan terhadap penyelenggara parkir di wilayah Kabupaten Bantul. Pengawasannya dipimpin oleh Tim Pengawasan dan Pengendalian (Wasdal) yang beranggotakan dari Dinas 
Perhubungan Kabupaten Bantul. Akan tetapi, beberapa penyelenggara parkir tidak bisa menyetorkan langsung hasil retribusi parkir kepada dinas perhubungan. Hal tersebut terjadi dikarenakan jarak yang cukup jauh antara tempat penyelenggara parkir dengan tempat untuk menyetorkan retribusi parkir yaitu dinas perhubungan. Maka Tim Wasdal mengambil hasil retribusi parkir dengan mendatangi langsung penyelenggara parkir. Sebelum mengambil hasil retribusi parkir tersebut, penyelenggara parkir telah berkoordinasi terlebih dahulu dengan dinas perhubungan yang menyatakan bahwa penyelenggara parkir tidak dapat menyetorkan hasil retribusi parkir kepada dinas perhubungan. Keempat, dalam kenyataan di lapangan, terdapat beberapa penyelenggara parkir terlambat untuk menyetorkan hasil retribusi parkir kepada dinas perhubungan. Salah satu alasan penyelenggara parkir terlambat untuk menyetor uang yaitu karena malas. Jadi untuk menyetorkan uang retribusi parkir tidak sebulan sekali, tetapi kadangkadang dua-tiga bulan sekali baru disetorkan kepada Dinas Perhubungan. Para penyelenggara parkir yang terlambat menyetorkan uang hasil pemungutan parkir tersebut tidak dikenakan sanksi maupun denda oleh dinas perhubungan. Karena dalam Perda Kabupaten Bantul, tidak diatur mengenai sanksi yang diberikan terhadap penyelenggara parkir yang terlambat menyetorkan uang hasil pemungutan parkir tersebut. Jadi uang tersebut masuk ke dalam piutang Dinas Perhubungan bukan termasuk dalam utang.

Berdasarkan hasil penelitian di atas, penulis menyarankan: pertama, Pemerintah Kabupaten Bantul dan Dinas Perhubungan harus membuat peraturan yang mengatur mekanisme mengenai bagi hasil retribusi parkir di tepi jalan umum antara penyelenggara parkir dengan pemerintah, sehingga bagi hasil retribusi parkir di tepi jalan umum tersebut tidak lagi berdasarkan kesepakatan antara penyelenggara parkir dengan pemerintah. Kedua, penyelenggara parkir harus memberikan karcis kepada pelanggan atau masyarakat yang memarkirkan kendaraannya tanpa harus diminta karcis terlebih dahulu. Ketiga, Pemerintah Kabupaten Bantul dan Dinas Perhubungan membuat mekanisme penyetoran hasil retribusi parkir di tepi jalan umum yang memudahkan penyelenggara parkir menyetorkan hasil retribusi parkir kepada Dinas Perhubungan, penyelenggara parkir tidak harus ke kantor Dinas Perhubungan melainkan bisa di setorkan 
melalui Bank yang bekerjasama dengan Pemerintah Daerah. Keempat, Pemerintah Kabupaten Bantul dan Dinas Perhubungan harus membuat peraturan yang mengatur mengenai sanksi yang diberikan kepada penyelenggara parkir apabila terlambat dalam menyetorkan hasil retribusi parkir di tepi jalan umum kepada Dinas Perhubungan. Kelima, Tim Wasdal dari Dinas Perhubungan harus lebih sering keliling untuk meninjau dan mengecek lokasi yang dijadikan tempat parkir dibawah Dinas Perhubungan, paling tidak satu kali dalam seminggu.

\section{Daftar Pustaka}

\section{Buku}

Bastian, Indra, Manual Akuntansi Keuangan Pemerintah Daerah, BPFE, Yogyakarta, 2001.

Bohari, Pengantar Hukum Pajak, PT Raja Grafindo Persada, Jakarta, 2002.

Hendratno, Edie Toet, Negara Kesatuan, Desentralisasi, dan Federalisme, Graha Ilmu, Yogyakarta, 2009.

Marbun, S.F, Hukum Administrasi Negara I, Ctk. Pertama, FH UII Press, Yogyakarta, 2012.

Mustaqiem, Pajak Daerah dalam Transisi Otonomi Daerah, Ctk. Pertama, FH UII Press, Yogyakarta, 2008.

Muyassarotussolichah, Hukum Pajak, Cetakan Pertama, Penerbit Teras, Yogyakarta, 2008.

Pandiangan, Liberty, Undang-Undang Perpajakan Indonesia, Gramedia, Jakarta, 2002.

Siahaan, Marihot P., Pajak Daerah dan Retribusi Daerah, PT Raja Grafindo Persada, Jakarta, 2006.

Tjandra, Riawan, Hukum Administrasi Negara, Sinar Grafika, Jakarta, 2018.

\section{Peraturan Perundang-Undangan}

Undang-Undang Dasar Negara Republik Indonesia tahun 1945

Undang-Undang Nomor 23 tahun 2014 tentang Pemerintahan Daerah

Undang-Undang Nomor 28 Tahun 2009 tentang Pajak Daerah dan Retribusi Daerah

Peraturan Daerah Nomor 19 Tahun 2015 tentang Jaringan Lalu Lintas dan Angkutan Jalan

Peraturan Daerah Nomor 09 Tahun 2011 tentang Retribusi Jasa Umum 